Ther Adv Endocrinol Metab

(2013) 4(4) 122-128

DOI: $10.1177 /$

2042018813501189

(c) The Author(s), 2013. Reprints and permissions http://www.sagepub.co.uk/ journalsPermissions.nav

\title{
Vitamin D and glycemic control in diabetes mellitus type 2
}

\author{
Ifigenia Kostoglou-Athanassiou, Panagiotis Athanassiou, Anastasios Gkountouvas \\ and Philippos Kaldrymides
}

\begin{abstract}
Objectives: The extraskeletal effects of vitamin D have attracted considerable interest. Vitamin $D$ deficiency appears to be related to the development of diabetes mellitus type 2 and the metabolic syndrome. Vitamin D may affect glucose homeostasis, vitamin D levels having been found to be inversely related to glycosylated hemoglobin levels in gestational diabetes mellitus. In addition, vitamin $\mathrm{D}$ appears to protect from the development of gestational diabetes mellitus. The aim was to study levels of 25 -hydroxy vitamin $\mathrm{D}_{3}\left[25(\mathrm{OH}) \mathrm{D}_{3}\right]$ and the relationship between $25(\mathrm{OH}) \mathrm{D}_{3}$ levels and glycemic control in patients with diabetes mellitus type 2 .

Methods: Glycosylated hemoglobin $\left(\mathrm{HbA} 1_{c}\right)$ and $25(0 \mathrm{H}) \mathrm{D}_{3}$ levels were measured in a group of 120 diabetes mellitus type 2 patients. The same measurements were performed in a group of 120 control subjects of the same age and sex. $25(\mathrm{OH}) \mathrm{D}_{3}$ was measured by radioimmunoassay and glycosylated hemoglobin $\left(\mathrm{HbA} 1_{\mathrm{c}}\right)$ was measured by high-performance liquid chromatography.

Results: $25(\mathrm{OH}) \mathrm{D}_{3}$ levels were lower in the diabetes mellitus type 2 patients than in the control group, being $19.26 \pm 0.95 \mathrm{ng} / \mathrm{ml}$ and $25.49 \pm 1.02 \mathrm{ng} / \mathrm{ml}$, in the patient and control groups, respectively $\left(p<0.001\right.$, Student's $t$-test). $25(\mathrm{OH}) \mathrm{D}_{3}$ levels were found to be inversely associated with $\mathrm{HbA} 1_{c}$ levels in the diabetic patients ( $p=0.008, r^{2}=0.058$, linear regression). $25(0 \mathrm{H}) \mathrm{D}_{3}$ levels were found to be inversely associated with $\mathrm{HbA}_{c}$ when the patient and control groups were analysed together $\left(p<0.001, r^{2}=0.086\right)$.

Conclusions: Vitamin D levels appeared to be lower in diabetes mellitus type 2 patients than in the control group, vitamin $D$ levels being related to glycemic control in diabetes mellitus type 2. These findings may have therapeutic implications as cautious vitamin $D$ supplementation may improve glycemic control in diabetes mellitus type 2 .
\end{abstract}

Keywords: diabetes mellitus type 2, glycemic control, vitamin D

Correspondence to: Ifigenia KostoglouAthanassiou, MSc, MD, PhD Department of Endocrinology, Red Cross Hospital, 7 Korinthias street, GR115 26 Athens, Greece ikostoglouathanassiouda yahoo.gr

Panagiotis Athanassiou, MD Department of Rheumatology, St. Paul's Hospital, Thessaloniki, Greece

Anastasios Gkountouvas, MD and Philippos Kaldrymides, MD Department of Endocrinology, Metaxa

Hospital, Pireaus, Greece

\section{Introduction}

Vitamin D is a hormone related to skeletal integrity [Holick, 2011]. Recently, the extraskeletal effects of vitamin $\mathrm{D}$ have raised considerable interest [Holick, 2008, 2010]. Vitamin D deficiency appears to be related to the development of diabetes mellitus type 2 [Pittas et al. 2007, 2010, 2012; Mitri et al. 2011; Chagas et al. 2012, Lim et al. 2013]. Mild to moderate vitamin D insufficiency has been proposed as a risk factor for type 2 diabetes [Pittas et al. 2007]. Higher plasma vitamin $\mathrm{D}$ has been shown to be related with a lower risk for the development of diabetes mellitus in high risk patients [Pittas et al. 2012]. Vitamin D deficiency has been described in the metabolic syndrome [Kayaniyil et al. 2013], specific vitamin $\mathrm{D}$ receptor gene polymorphisms having been found to be related to components of the metabolic syndrome [Schuch et al. 2013]. Moreover, vitamin D seems to affect glucose homeostasis, vitamin D levels having been found to be inversely related to glycosylated hemoglobin levels in gestational diabetes mellitus [Lau et al. 2011]. In addition, vitamin D deficiency seems to be related with an increased risk for the development of gestational diabetes mellitus [Aghajafari 
et al. 2013; Wei et al. 2013]. We hypothesized that vitamin $\mathrm{D}$ deficiency may be prevalent in a population of diabetes mellitus type 2 patients and that vitamin $\mathrm{D}$ may be related to glucose control in this group of patients.

The aim was to study levels of 25-hydroxy vita$\min \mathrm{D}_{3}\left[25(\mathrm{OH}) \mathrm{D}_{3}\right]$ and the relationship between $25(\mathrm{OH}) \mathrm{D}_{3}$ levels and glycemic control in patients with diabetes mellitus type 2 .

\section{Methods}

To test the hypothesis that $25(\mathrm{OH}) \mathrm{D}_{3}$ levels may be lower in a cohort of diabetes mellitus type 2 patients and that $25(\mathrm{OH}) \mathrm{D}_{3}$ levels may be related to glucose control in this group of patients, $25(\mathrm{OH}) \mathrm{D}_{3}$ and $\mathrm{HbA} 1_{c}$ levels were measured in diabetes mellitus type 2 patients and controls. In a group of 120 consecutive diabetes mellitus type 2 patients, aged $25-82$ years, mean age $56.8 \pm 1.1$ years, $25(\mathrm{OH}) \mathrm{D}_{3}$ levels and glycosylated hemoglobin $\left(\mathrm{HbA} 1_{c}\right)$ levels were measured. The study population consisted of 120 diabetes mellitus type 2 patients from the area of Athens and Pireaus. The study was conducted over a period of a year during the winter and spring. The same measurements were performed in a group of 120 normal subjects of the same sex and age, who served as controls. The cohort of 120 diabetes mellitus type 2 patients included in the study were on treatment either with diet only or with diet and oral antidiabetic drugs. The study was approved by the ethics committee of Metaxa Hospital.

Levels of $25(\mathrm{OH}) \mathrm{D}_{3}$ were measured by radioimmunoassay (RIA) in a two-step procedure. The first step involved rapid extraction of $25(\mathrm{OH}) \mathrm{D}$ and other hydroxylated metabolites from serum or plasma with acetonitrile. Following extraction, the treated samples were assayed by competitive RIA using an antibody with specificity to $25(\mathrm{OH})$ D. The sample, antibody and tracer were incubated for $90 \mathrm{~min}$ at $20-25^{\circ} \mathrm{C}$. Phase separation was accomplished after $20 \mathrm{~min}$ incubation at 20 $25^{\circ} \mathrm{C}$ with a second antibody precipitating complex. To reduce nonspecific binding, buffer was added after this incubation prior to centrifugation. The sensitivity of the assay was $<1.6 \mathrm{ng} / \mathrm{ml}$. The recovery was approximately $100 \%$ for $25(\mathrm{OH}) \mathrm{D}_{3}$. Within and between batch precision was $<12 \%$ and $<11 \%$, respectively.

Levels of $\mathrm{HbA} 1_{c}$ were measured by high-performance liquid chromatography (HPLC), with a within run coefficient of variation of $0.78 \%$, a between run coefficient of variation of $0.52 \%$ and a total precision of $1.16 \%$. HbA $1_{c}$ was chromatographically separated on a cation exchange cartridge. The method utilizes principles of ion-exchange liquid chromatography. Samples were automatically diluted and injected into the analytical cartridge. A programmed buffer gradient of increasing ionic strength was delivered to the cartridge, where the hemoglobins were separated based on their ionic interactions with the cartridge material. The separated hemoglobins then passed through the flow cell of a filter photometer.

Statistical evaluation of the results was performed using the statistical package SPSS19. Student's $t$-test was used to compare the patient group with the control group. Regression analysis was performed to analyse the relationship between $\mathrm{HbA} 1_{c}$ and $25(\mathrm{OH}) \mathrm{D}_{3}$ levels. In order to test normality of the parameters involved in regression analysis, histograms of regression standardized residuals and $p-p$ plots of regression standardized residuals were performed. A chi-squared test was performed to compare the number of subjects with vitamin $\mathrm{D}$ deficiency and insufficiency within the patient and control groups.

\section{Results}

$\mathrm{HbA} 1_{\mathrm{c}}$ levels were higher in the group of diabetes mellitus type 2 patients than in the control group, $\mathrm{HbA} 1_{\mathrm{c}}$ levels being $7.2 \pm 0.18 \%$ and $5.1 \pm 0.05$ $\%$ in the patient and control groups, respectively $(p<0.001$, Student's $t$-test) (Table 1$)$. In the group of diabetes mellitus type 2 patients, $25(\mathrm{OH}) \mathrm{D}_{3}$ levels were lower than in the control group, $25(\mathrm{OH}) \mathrm{D}_{3}$ levels being $19.26 \pm 0.94 \mathrm{ng} / \mathrm{ml}$ and $25.48 \pm 1.02 \mathrm{ng} / \mathrm{ml}$ in the patient and control group, respectively $(p<0.001)$ (Table 1$)$.

In the group of diabetes mellitus type 2 patients, 21 of $120(17.5 \%)$ as opposed to 7 of $120(5.8 \%)$ in the control group had vitamin D deficiency, $25(\mathrm{OH}) \mathrm{D}_{3}$ levels $\leq 10 \mathrm{ng} / \mathrm{ml}$ (chi-squared test, $p=0.0089)$. In the group of diabetes mellitus type 2 patients, 76 of $120(63.3 \%)$ as opposed to 28 of $120(23.3 \%)$ in the control group had vitamin $\mathrm{D}$ insufficiency, $25(\mathrm{OH}) \mathrm{D}_{3}$ levels $<20 \mathrm{ng} / \mathrm{ml}$ (chi-squared test, $p<0.0001$ ) (Table 1 ).

$25(\mathrm{OH}) \mathrm{D}_{3}$ levels were found to be inversely associated with $\mathrm{HbA} 1_{\mathrm{c}}$ levels in the group of diabetic type 2 patients $(p=0.008, r=0.058$, linear regression analysis) (Figure 1). When the analysis was 
Table 1. $25(\mathrm{OH}) \mathrm{D}_{3}(\mathrm{ng} / \mathrm{ml}$ ) (mean $\pm \mathrm{SEM}), \mathrm{HbA} 1_{\mathrm{c}}(\%)$ (mean $\pm \mathrm{SEM}$ ) in the diabetes mellitus type 2 patients ( $n=120)$ and controls ( $n=120$ ) and statistical significance (Student's $t$-test), number and percentage of subjects with $25(\mathrm{OH}) D_{3}$ deficiency and insufficiency $\left[25(\mathrm{OH}) \mathrm{D}_{3} \leq 10 \mathrm{ng} / \mathrm{ml}\right.$ and $\left.<20 \mathrm{ng} / \mathrm{ml}\right]$ in the patient and control groups and statistical significance (chi-squared test).

\begin{tabular}{|c|c|c|c|c|}
\hline \multirow[t]{2}{*}{ Subjects } & \multirow[t]{2}{*}{$\begin{array}{l}\mathrm{HbA} 1_{\mathrm{c}}(\%) \\
\text { mean } \pm \text { SEM }\end{array}$} & \multirow[t]{2}{*}{$\begin{array}{l}25(\mathrm{OH}) \mathrm{D}_{3}(\mathrm{ng} / \mathrm{ml}) \\
\text { mean } \pm \text { SEM }\end{array}$} & \multicolumn{2}{|l|}{$25(\mathrm{OH}) \mathrm{D}_{3}$} \\
\hline & & & $\leq 10 \mathrm{ng} / \mathrm{ml}$ & $<20 \mathrm{ng} / \mathrm{ml}$ \\
\hline Patients & $7.2 \pm 0.18$ & $19.26 \pm 0.94$ & $21(17.5 \%)$ & $76(63.3 \%)$ \\
\hline Controls & $5.1 \pm 0.05$ & $25.48 \pm 1.02$ & $7(5.8 \%)$ & $28(23.3 \%)$ \\
\hline Statistical significance & $p<0.001$ & $p<0.001$ & $p=0.0089$ & $p<0.0001$ \\
\hline
\end{tabular}

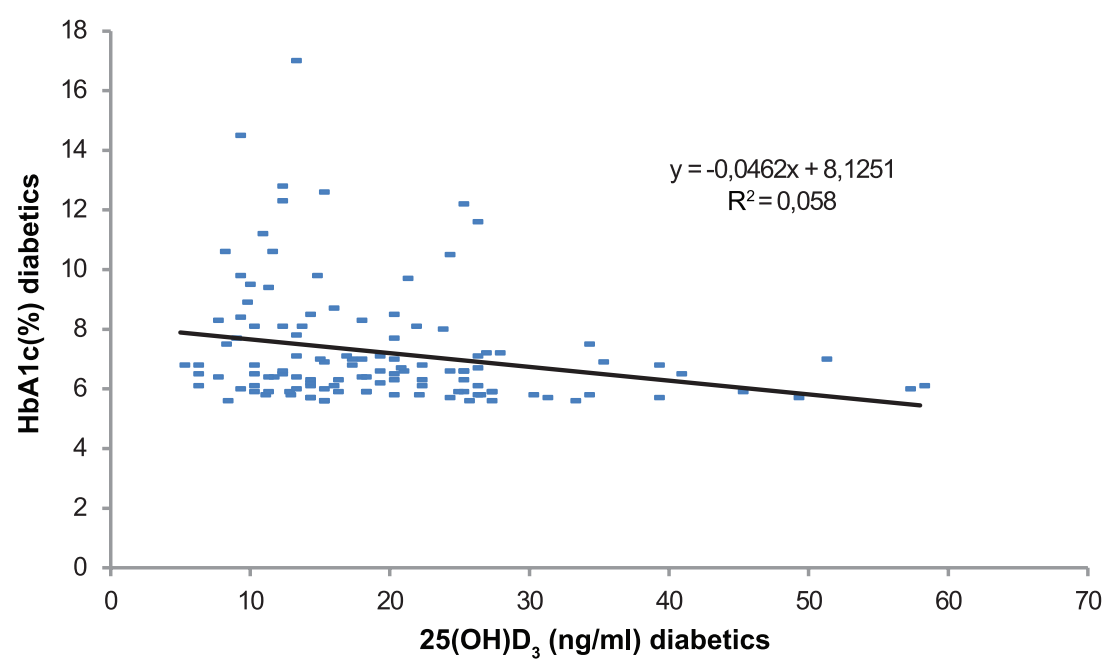

Figure 1. Inverse association between $25(\mathrm{OH}) \mathrm{D}_{3}(\mathrm{ng} / \mathrm{ml})$ and $\mathrm{HbA} 1_{\mathrm{c}}(\%)$ in diabetes mellitus type 2 patients, ( $p=0.008, r^{2}=0.058$, linear regression analysis $)$.

$25(\mathrm{OH}) \mathrm{D}_{3}, 25$-hydroxy vitamin $\mathrm{D}_{3} ; \mathrm{HbA1}_{\mathrm{c}}$, glycosylated haemoglobin.

performed in the complete population studied, diabetes mellitus type 2 patients and controls, it was found that $25(\mathrm{OH}) \mathrm{D}_{3}$ levels were inversely associated with $\mathrm{HbA}_{\mathrm{c}}$ levels $\left(p<0.001, r^{2}=\right.$ 0.086) (Figure 2).

\section{Discussion}

In the present study, lower $25(\mathrm{OH}) \mathrm{D}_{3}$ levels were observed in a cohort of diabetes mellitus type 2 patients than in a control group and an inverse relationship was observed between glycosylated hemoglobin levels and $25(\mathrm{OH}) \mathrm{D}_{3}$ levels in the patient group, implying that $25(\mathrm{OH}) \mathrm{D}_{3}$ levels may affect glucose control in diabetes mellitus type 2. Interestingly, an inverse relationship was found between vitamin D levels and glycosylated hemoglobin in the whole population studied, diabetes mellitus type 2 patients and controls when analysed together. It appears that vitamin D may be related to glucose control in diabetes mellitus type 2 . In addition, statistically significantly more diabetes mellitus type 2 patients than the control population had vitamin $\mathrm{D}$ deficiency and insufficiency.

Vitamin D is related to bone metabolism, being a secosteroid synthesized in the skin by the action of ultraviolet irradiation from the sun. The extraskeletal effects of vitamin D are currently the focus of research efforts [Rosen et al. 2012]. The relationship of vitamin D with the immune system is being intensely discussed. It has been shown that vitamin $\mathrm{D}$ induces immune tolerance [Weiss, 2011], vitamin D deficiency being related to the development of autoimmune diseases, such as multiple sclerosis [Ho et al. 2012; Holmøy et al. 2012, Weinstock-Guttman et al. 2012], 


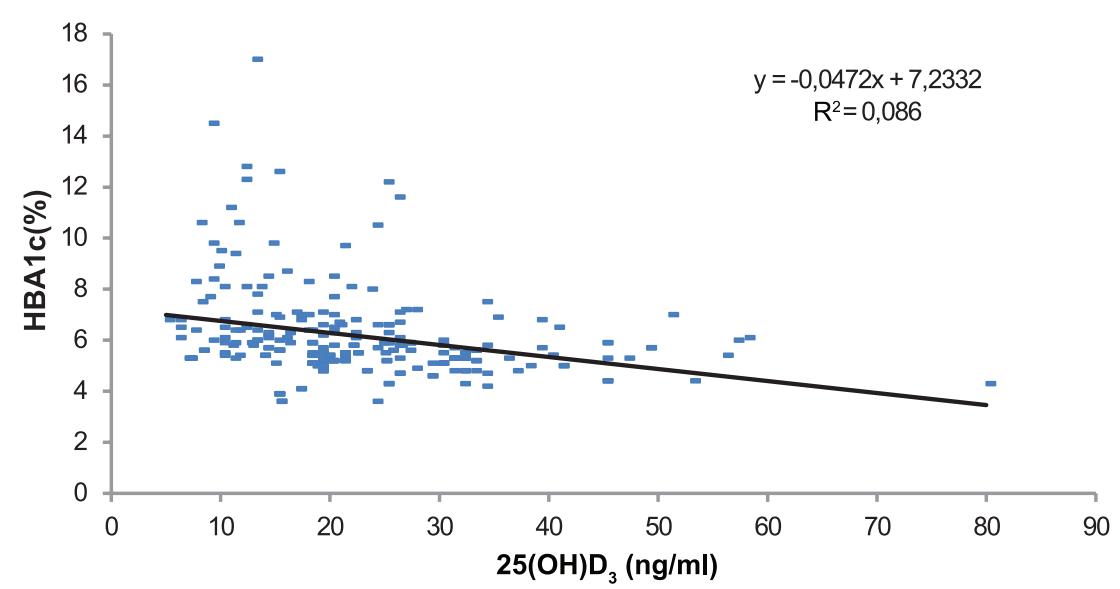

Figure 2. Inverse association between $25(\mathrm{OH}) \mathrm{D}_{3}(\mathrm{ng} / \mathrm{ml})$ and $\mathrm{HbA} 1_{\mathrm{c}}(\%)$ in the whole population studied, diabetes mellitus type 2 patients and controls ( $p<0.001, r^{2}=0.086$, linear regression analysis).

$25(\mathrm{OH}) \mathrm{D}_{3}, 25$-hydroxy vitamin $\mathrm{D}_{3} ; \mathrm{HbA} 1_{c}$, glycosylated haemoglobin.

rheumatoid arthritis [Cutolo et al. 2007; Haga et al. 2013] and diabetes mellitus type 1 [Hyppönen et al. 2001]. Recently, the relationship between vitamin D and diabetes mellitus type 2 and the metabolic syndrome has been debated [Palomer et al. 2008; Tai et al. 2008; Maxwell and Wood, 2011; Mezza et al. 2012; Lim et al. 2013]. Vitamin D has been shown to be related to glucose metabolism and the development of diabetes mellitus type 2 and the metabolic syndrome [Pittas et al. 2007; Mezza et al. 2012; Lim et al. 2013; Kayaniyil et al. 2013].

In a cross-sectional analysis of a general population sample in eastern Finland, an inverse association was observed between $25(\mathrm{OH}) \mathrm{D}_{3}$ levels and fasting insulin, fasting glucose and $2 \mathrm{~h}$ glucose tolerance test glucose results [Hurskainen et al. 2012], implying that low serum $25(\mathrm{OH}) \mathrm{D}_{3}$ may be associated with impaired glucose metabolism. In a recent study, an inverse association of insulin resistance with $25(\mathrm{OH}) \mathrm{D}_{3}$ levels was observed which was principally found at $25(\mathrm{OH}) \mathrm{D}_{3}$ levels between 16 and $36 \mathrm{ng} / \mathrm{ml}$ [Heaney et al. 2013]. In a nested case-control study conducted among 608 women with newly diagnosed type 2 diabetes, higher plasma $25(\mathrm{OH}) \mathrm{D}_{3}$ concentration was associated with lower risk of type 2 diabetes in women [Pittas et al. 2010]. In a prospective observational study with a mean follow up of 2.7 years, higher plasma $25(\mathrm{OH}) \mathrm{D}_{3}$ assessed repeatedly was associated with a lower risk of incident diabetes in high-risk patients [Pittas et al. 2012]. In a prospective study in high risk Asian subjects, $25(\mathrm{OH}) \mathrm{D}_{3}$ deficiency was associated with a higher risk for the development of type 2 diabetes mellitus. In a longitudinal study of the determinants of insulin resistance and the metabolic syndrome, a significant inverse association of baseline $25(\mathrm{OH}) \mathrm{D}_{3}$ with fasting glucose at follow up was observed [Kayaniyil et al. 2013]. In a large cohort study of older adults involving 7791 subjects, initially diabetes-free, serum $25(\mathrm{OH}) \mathrm{D}$ levels were inversely associated with incident diabetes in women but not in men [Schöttker et al. 2013].

Previous studies have shown that low vitamin D ingestion may be related with a higher risk for the development of diabetes mellitus type 2 and the metabolic syndrome [Liu et al. 2005; Pittas et al. 2006].

In the present study, lower $25(\mathrm{OH}) \mathrm{D}_{3}$ levels were observed in diabetes mellitus type 2 patients than in controls. In an earlier study, vitamin D deficiency was found to be related to a higher risk for insulin resistance and the metabolic syndrome [Chiu et al. 2004]. In a study involving 8421 participants from the National Health and Nutrition Examination Survey III (NHANES III), significantly lower levels of $25(\mathrm{OH}) \mathrm{D}$ were observed in the subjects with metabolic syndrome than in those without it [Ford et al. 2005]. In a study in postmenopausal women, fasting glucose levels were found to be negatively correlated with serum 25(OH)D [Need et al. 2005].

In the present study, vitamin D levels were found to be negatively correlated with glycosylated hemoglobin levels. The correlation persisted even after outliers were excluded. Recent work has shown that vitamin $\mathrm{D}$ levels may be inversely 
related with glycosylated hemoglobin levels in gestational diabetes mellitus [Lau et al. 2011]. In addition, it has been suggested that adequate vitamin D intake may be related with a lower risk for the development of gestational diabetes mellitus [Alzaim and Wood, 2013].

Vitamin D receptors have been found in pancreatic beta cells [Johnson et al. 1994], which additionally have been found to express the enzyme 1- $\alpha$-hydroxylase [Bland et al. 2004]. Vitamin D facilitates the secretion of insulin from pancreatic beta cells, thus appearing to regulate insulin secretion [Bourlon et al. 1999; Zeitz et al. 2003]. Therefore vitamin $\mathrm{D}$ deficiency may be related to impaired insulin secretion in diabetes mellitus type 2 . In addition, as vitamin D stimulates the expression of the insulin receptor [Maestro et al. 2000], vitamin D deficiency may be related with insulin resistance [Talaei et al. 2013].

Based on these results it would be physiologically correct to recommend vitamin D supplementation to improve glucose control in type 2 diabetes mellitus patients [Osei, 2010]. Accordingly, vitamin $\mathrm{D}$ has been administered to patients with diabetes mellitus type 2 [Borissova et al. 2008; Al-Daghri et al. 2012; Heshmat et al. 2012; Breslavsky et al. 2013]. However, these studies have not shown consistent results. In some studies vitamin $\mathrm{D}$ supplementation was found to improve glucose control in diabetes mellitus type 2 [Borissova et al. 2008; Al-Daghri et al. 2012], while in others no such effect was observed [Heshmat et al. 2012; Breslavsky et al. 2013]. In a randomized controlled trial, the administration of 2000 international units (IU) cholecalciferol daily for 16 weeks was found to improve beta cell function in adults at high risk for diabetes [Mitri et al. 2011]. In addition, vitamin D was administered to type 2 diabetics with nephropathy and was found to ameliorate albuminuria [Huang et al. 2012]. At a molecular level vitamin D appears to reduce oxidative stress [Salum et al. 2013].

The present study has several limitations. It is an observational study and therefore no conclusion can be made as far as any cause and effect relationship is concerned between vitamin D deficiency and diabetes mellitus type 2 . In addition, $25(\mathrm{OH}) \mathrm{D}_{3}$ was chosen as a marker of vitamin $\mathrm{D}$ deficiency, as currently recommended. However, vitamin $\mathrm{D}$ circulates in several forms in the blood and its active form is $1,25(\mathrm{OH})_{2} \mathrm{D}_{3}$. As such, more studies are needed using finer tools for the determination of vitamin D deficiency in the human and in particular, in diabetics. More studies are also needed with vitamin D supplementation and long-term observation of glucose control in diabetes mellitus type 2 .

Having discussed these results the hidden relationship between vitamin $\mathrm{D}$ deficiency and various diseases remains to be unravelled [Chagas et al. 2012].Vitamin D may be related to autoimmunity as well as to metabolic diseases [Holick, 2012]. In addition, recent work has been set forward which discusses the relationship of vitamin $\mathrm{D}$ with adipose tissue. It appears that vitamin $\mathrm{D}$ may affect adipogenesis [Ochs-Balcom et al. 2011; Landrier et al. 2012], thus modulating energy expenditure in adipose tissue. These new findings may explain why the administration of vitamin $\mathrm{D}$ to patients with diabetes mellitus and the metabolic syndrome appears to have contradictory results.

The findings presented herein have therapeutic implications. In patients with diabetes mellitus type 2, normal levels of vitamin $\mathrm{D}$ in the blood may facilitate glucose control. In addition, in people with a tendency to develop diabetes mellitus type 2, optimal levels of vitamin $\mathrm{D}$ within the blood may retard the clinical development of diabetes mellitus type 2 .

\section{Funding}

This research received no specific grant from any funding agency in the public, commercial or notfor-profit sectors.

\section{Conflict of interest statement}

The authors declare no conflicts of interest in preparing this article.

\section{References}

Al-Daghri, N.M., Alkharfy, K.M., Al-Othman, A., El-Kholie, E., Moharram, O., Alokail, M.S. et al. (2012) Vitamin D supplementation as an adjuvant therapy for patients with T2DM: an 18-month prospective interventional study. Cardiovasc Diabetol 11: 85.

Aghajafari, F., Nagulesapillai, T., Ronksley, P., Tough, S., O'Beirne, M. and Rabi, D.

(2013) Association between maternal serum 25-hydroxyvitamin D level and pregnancy and neonatal outcomes: systematic review and metaanalysis of observational studies. BMF 346: f1 169.

Alzaim, M. and Wood, R. (2013) Vitamin D and gestational diabetes mellitus. Nutr Rev 71:158-167. 
Bland, R., Markovic, D., Hills, C., Hughes, S., Chan, S., Squires, P. et al. (2004) Expression of 25-hydroxyvitamin D3-1alpha-hydroxylase in pancreatic islets. F Steroid Biochem Mol Biol 89-90: 121-125.

Borissova, A., Tankova, T., Kirilov, G., Dakovska, L. and Kovacheva, R. (2003) The effect of vitamin D3 on insulin secretion and peripheral insulin sensitivity in type 2 diabetic patients. Int $\mathcal{F}$ Clin Pract 57: 258-261.

Bourlon, P., Billaudel, B. and Faure-Dussert, A. (1999) Influence of vitamin D3 deficiency and 1,25 dihydroxyvitamin D3 on de novo insulin biosynthesis in the islets of the rat endocrine pancreas. $\mathcal{F}$ Endocrinol 160: 87-95.

Breslavsky, A., Frand, J., Matas, Z., Boaz, M., Barnea, Z. and Shargorodsky, M. (2013) Effect of high doses of vitamin $\mathrm{D}$ on arterial properties, adiponectin, leptin and glucose homeostasis in type 2 diabetic patients. Clin Nutr [Epub ahead of print]

Chagas, C., Borges, M., Martini, L. and Rogero, M. (2012) Focus on vitamin D, inflammation and type 2 diabetes. Nutrients 4: 52-67.

Chiu, K., Chu, A., Go, V. and Saad, M. (2004) Hypovitaminosis D is associated with insulin resistance and beta cell dysfunction. Am F Clin Nutr 79: 820-825.

Cutolo, M., Otsa, K., Uprus, M., Paolino, S. and Seriolo, B. (2007) Vitamin D in rheumatoid arthritis. Autoimmun Rev 7: 59-64.

Ford, E., Ajani, U., McGuire, L. and Liu, S. (2005) Concentrations of serum vitamin D and the metabolic syndrome among U.S. adults. Diabetes Care 28: 1228-1230.

Haga, H., Schmedes, A., Naderi, Y., Moreno, A. and Peen, E. (2013) Severe deficiency of 25-hydroxyvitamin $\mathrm{D}$ (3) (25-OH-D (3)) is associated with high disease activity of rheumatoid arthritis. Clin Rheumatol 32: 629-633.

Heaney, R., French, C., Nguyen, S., Ferreira, M., Baggerly, L., Brunel, L. et al. (2013) A novel approach localizes the association of vitamin $\mathrm{d}$ status with insulin resistance to one region of the 25-hydroxyvitamin D continuum. Adv Nutr 4: 303-310.

Heshmat, R., Tabatabaei-Malazy, O., AbbaszadehAhranjani, S., Shahbazi, S., Khooshehchin, G., Bandarian, F. et al. (2012) Effect of vitamin D on insulin resistance and anthropometric parameters in Type 2 diabetes: a randomized double-blind clinical trial. Daru 20: 10.

Ho, S., Alappat, L. and Awad, A. (2012) Vitamin D and multiple sclerosis. Crit Rev Food Sci Nutr 52: 980-987.
Holick, M. (2008) The vitamin D deficiency pandemic and consequences for nonskeletal health: mechanisms of action. Mol Aspects Med 29: 361-368.

Holick, M. (2010) Vitamin D: extraskeletal health. Endocrinol Metab Clin North Am 39: 381-400.

Holick, M. (2011) Vitamin D: evolutionary, physiological and health perspectives. Curr Drug Targets 12: 4-18.

Holick, M. (2012) Evidence-based D-bate on health benefits of vitamin D revisited. Dermatoendocrinology 4: 183-190.

Holmøy, T., Kampman, M. and Smolders, J. (2012) Vitamin D in multiple sclerosis: implications for assessment and treatment. Expert Rev Neurother 12: 1101-1112.

Huang, Y., Yu, H., Lu, J., Guo, K., Zhang, L., Bao, Y. et al. (2012) Oral supplementation with cholecalciferol 800 IU ameliorates albuminuria in Chinese type 2 diabetic patients with nephropathy. PLoS One 7: e50510.

Hurskainen, A., Virtanen, J., Tuomainen, T., Nurmi, T. and Voutilainen, S. (2012) Association of serum 25-hydroxyvitamin $\mathrm{D}$ with type 2 diabetes and markers of insulin resistance in a general older population in Finland. Diabetes Metab Res Rev 28: 418-423.

Hyppönen, E., Läärä, E., Reunanen, A., Järvelin, M. and Virtanen, S. (2001) Intake of vitamin D and risk of type 1 diabetes: a birth-cohort study. Lancet 358: 1500-1503.

Johnson, J., Grande, J., Roche, P. and Kumar, R. (1994) Immunohistochemical localization of the $1,25(\mathrm{OH}) 2 \mathrm{D} 3$ receptor and calbindin D28k in human and rat pancreas. Am $\mathcal{F}$ Physiol 267: E356-360.

Kayaniyil, S., Harris, S., Retnakaran, R., Vieth, R., Knight, J., Gerstein, H. et al. (2013) Prospective association of $25(\mathrm{OH}) \mathrm{D}$ with metabolic syndrome. Clin Endocrinol (Oxford) [Epub ahead of print]

Landrier, J., Marcotorchino, J. and Tourniaire, F. (2012) Lipophilic micronutrients and adipose tissue biology. Nutrients 4: 1622-1649.

Lau, S., Gunton, J., Athayde, N., Byth, K. and Cheung, N. (2011) Serum 25-hydroxyvitamin D and glycated haemoglobin levels in women with gestational diabetes mellitus. Med F Aust 194: 334-337.

Lim, S., Kim, M., Choi, S., Shin, C., Park, K., Jang, H. et al. (2013) Association of vitamin D deficiency with incidence of type 2 diabetes in high-risk Asian subjects. Am f Clin Nutr 97: 524-530.

Liu, S., Song, Y., Ford, E., Manson, J., Buring, J. and Ridker, P. (2005) Dietary calcium, vitamin D, and the prevalence of metabolic syndrome in middle-aged and older U.S. women. Diabetes Care 28: 2926-2932. 
Maestro, B., Campión, J., Dávila, N. and Calle, C. (2000) Stimulation by 1,25-dihydroxyvitamin D3 of insulin receptor expression and insulin responsiveness for glucose transport in U-937 human promonocytic cells. Endocr F 47: 383-391.

Maxwell, C. and Wood, R. (2011) Update on vitamin D and type 2 diabetes. Nutr Rev 69: 291-295.

Mezza, T., Muscogiuri, G., Sorice, G., Prioletta, A., Salomone, E., Pontecorvi, A. et al. (2012) Vitamin D deficiency: a new risk factor for type 2 diabetes?. Ann Nutr Metab 61: 337-348.

Mitri, J., Dawson-Hughes, B., Hu, F. and Pittas, A. (2011) Effects of vitamin D and calcium supplementation on pancreatic $\beta$ cell function, insulin sensitivity, and glycemia in adults at high risk of diabetes: the Calcium and Vitamin D for Diabetes Mellitus (CaDDM) randomized controlled trial. Am $\mathcal{F}$ Clin Nutr 94: 486-494.

Need, A., O'Loughlin, P., Horowitz, M. and Nordin, B. (2005) Relationship between fasting serum glucose, age, body mass index and serum 25 hydroxyvitamin D in postmenopausal women. Clin Endocrinol (Oxford) 62: 738-741.

Ochs-Balcom, H., Chennamaneni, R., Millen, A., Shields, P., Marian, C., Trevisan, M. et al. (2011) Vitamin D receptor gene polymorphisms are associated with adiposity phenotypes. Am F Clin Nutr 93: 5-10.

Osei, K. (2010) 25-OH vitamin D: is it the universal panacea for metabolic syndrome and type 2 diabetes? f Clin Endocrinol Metab 95: 4220-4222.

Palomer, X., González-Clemente, J., Blanco-Vaca, F. and Mauricio, D. (2008) Role of vitamin D in the pathogenesis of type 2 diabetes mellitus. Diabetes Obes Metab 10: 185-197.

Pittas, A., Dawson-Hughes, B., Li, T., Van Dam, R., Willett, W., Manson, J. et al. (2006) Vitamin D and calcium intake in relation to type 2 diabetes in women. Diabetes Care 29: 650-656.

Pittas, A., Lau, J., Hu, F. and Dawson-Hughes, B. (2007) The role of vitamin D and calcium in type 2 diabetes. A systematic review and meta-analysis. $\mathcal{F}$ Clin Endocrinol Metab 92: 2017-2029.

Pittas, A., Nelson, J., Mitri, J., Hillmann, W., Garganta, C., Nathan, D. et al. (2012) Plasma 25-hydroxyvitamin Visit SAGE journals online http://tae.sagepub.com

@SAGE journals
$\mathrm{D}$ and progression to diabetes in patients at risk for

diabetes: an ancillary analysis in the Diabetes Prevention Program. Diabetes Care 35: 565-573.
Pittas, A., Sun, Q., Manson, J., Dawson-Hughes, B. and Hu, F. (2010) Plasma 25-hydroxyvitamin D concentration and risk of incident type 2 diabetes in women. Diabetes Care 33: 2021-2023.

Rosen, C., Adams, J., Bikle, D., Black, D., Demay, M., Manson, J. et al. (2012) The nonskeletal effects of vitamin D: an Endocrine Society scientific statement. Endocr Rev 33: 456-492.

Salum, E., Kals, J., Kampus, P., Salum, T., Zilmer, K., Aunapuu, M. et al. (2013) Vitamin D reduces deposition of advanced glycation end- products in the aortic wall and systemic oxidative stress in diabetic rats. Diabetes Res Clin Pract 100: 243-249.

Schöttker, B., Herder, C., Rothenbacher, D., Perna, L., Müller, H. and Brenner, H. (2013) Serum 25-hydroxyvitamin D levels and incident diabetes mellitus type 2: a competing risk analysis in a large population-based cohort of older adults. Eur $\mathcal{F}$ Epidemiol 28: 267-275.

Schuch, N., Garcia, V., Vívolo, S. and Martini, L. (2013) Relationship between Vitamin D receptor gene polymorphisms and the components of metabolic syndrome. Nutr f 12: 96.

Tai, K., Need, A., Horowitz, M. and Chapman, I. (2008) Vitamin D, glucose, insulin, and insulin sensitivity. Nutrition 24: 279-285.

Talaei, A., Mohamadi, M. and Adgi, Z. (2013) The effect of vitamin $\mathrm{D}$ on insulin resistance in patients with type 2 diabetes. Diabetol Metab Syndr 5: 8.

Wei, S., Qi, H., Luo, Z. and Fraser, W. (2013) Maternal vitamin D status and adverse pregnancy outcomes: a systematic review and meta-analysis. f Matern Fetal Neonatal Med 26: 889-899.

Weinstock-Guttman, B., Mehta, B., Ramanathan, M., Karmon, Y., Henson, L., Halper, J. et al. (2012) Vitamin D and multiple sclerosis. Neurologist 18 : 179-183.

Weiss, S. (2011) Bacterial components plus vitamin $\mathrm{D}$ : the ultimate solution to the asthma (autoimmune disease) epidemic? F Allergy Clin Immunol 127: 1128-1130.

Zeitz, U., Weber, K., Soegiarto, D., Wolf, E., Balling, R. and Erben, R. (2003) Impaired insulin secretory capacity in mice lacking a functional vitamin D receptor. FASEB $\mathcal{F}$ 17: 509-511. 